\title{
Pemberdayaan masyarakat UKM dalam mengimplementasikan unique selling proposition dan strategi penentuan harga jual
}

\author{
Yunika Murdayanti *, Susi Indriani, Etty Gurendrawati, I Gusti Ketut Agung Ulupui, \\ Suherman Suherman \\ Universitas Negeri Jakarta. Jalan Rawamangun Muka Jakarta Timur 13220, Indonesia \\ *Corresponding Author. Email: yunika_murdayanti@unj.ac.id
}

Received: 19 January 2020; Revised: 9 June 2020; Accepted: 1 July 2020

\begin{abstract}
Abstrak: Perkembangan UKM saat ini mendapatkan perhatian yang besar baik dari pemerintah maupun masyarakat agar dapat berkembang lebih kompetitif bersama pelaku ekonomi lainnya. Bagian penting dari suatu ekosistem wirausaha adalah dalam membuka peluang memperluas jangkauan pemasaran produk-produk mereka, bahkan hingga ke luar negeri yaitu dengan unique selling proposition yang baik dan strategi penentuan harga jual yang kompetitif di pasaran. Pengabdian ini dilakukan di Desa Segara Jaya Bekasi Jawa Barat melalui metode wawancara, ceramah dan tatap muka serta diskusi. Pencapaian kegiatan ini adalah dihasilkannya peningkatan kompetensi para pedagang UKM dalam penentuan harga jual, memahami strategi dalam memasarkan produk, berkurangnya distribusi produk kepada para tengkulak, mampu membuat bentuk produk yang unik dan kompetitif di pasaran, mudah memiliki jaringan kerjasama. Saran agar pelatihan ini dapat berkesinambungan dengan periode yang lebih panjang dan materi yang lebih komprehensif.
\end{abstract}

Kata Kunci: kewirausahaan, unique selling proposition, strategi penentuan harga jual

\section{Community empowerment of SME in implementation of unique selling proposition and selling price determination strategies}

\begin{abstract}
The development of SME's receives a great attention from both government and communities in order to develop competitively with other economic actors. An important part of entrepreneurial ecosystem is opening opportunities to expand the marketing of their products to go abroad with a good unique selling proposition and competitive pricing strategies. This community empowerment took place at Segara Jaya Village, Bekasi, West Java through interviews, lectures, face-to-face methods and discussions. The conclusions of this activities resulted an increase of the competence of SME traders in determining selling prices, understanding strategies in marketing products, reducing product distribution to middlemen, being able to create unique and competitive forms of products in the market, also easily having a network of cooperation. Suggestions that this training can be continued with a longer period and more comprehensive material.
\end{abstract}

Keywords: entrepreneurship, unique selling proposition, selling price determination strategies

How to Cite: Murdayanti, Y., Indriani, S., Gurendrawati, E., Ulupui, I., \& Suherman, S. (2020). Pemberdayaan masyarakat UKM dalam mengimplementasikan unique selling proposition dan strategi penentuan harga jual. JPPM (Jurnal Pendidikan dan Pemberdayaan Masyarakat), 7(1), 65-77. doi:https://doi.org/10.21831/jppm.v7i1.29707

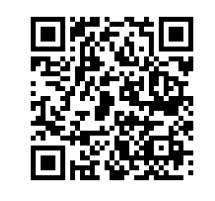

\section{PENDAHULUAN}

Perkembangan UKM saat ini mendapatkan perhatian yang besar baik dari pemerintah maupun masyarakat agar dapat berkembang lebih kompetitif bersama pelaku ekonomi lainnya. Kehadiran para pelaku di usaha mikro, kecil, dan menengah (UMKM) merupakan bagian terpenting dalam perekonomian di Indonesia karena menjadi salah satu motor penggerak terbesar (Putri \& Nailufar, 2019). Kebijakan pemerintah ke depan bertujuan menuju kondisi yang lebih kondusif bagi tumbuh dan berkembangnya UKM (Wuryandani \& Meilani, 2013). Pemerintah perlu meningkatkan perannya dalam memberdayakan UKM di samping engembangkan 
JPPM (Jurnal Pendidikan dan Pemberdayaan Masyarakat), 7 (1), 2020 - 66

Yunika Murdayanti, Susi Indriani, Etty Gurendrawati, IGKA Ulupui, Suherman

kemitraan usaha yang saling menguntungkan antara pengusaha besar dengan pengusaha kecil, dan meningkatkan kualitas Sumber Daya Manusianya. Mayoritas, para pedagang UKM sudah menggunakan media teknologi informasi dalam memasarkan produknya. Teknologi Informasi sangat membantu pelaku UKM untuk dapat menyikapi kondisi disruptif yang didorong perkembangan teknologi digital. Ini juga merupakan bagian penting dari ekosistem wirausaha, terutama dalam membuka peluang memperluas jangkauan pemasaran produk-produk mereka, bahkan hingga ke luar negeri.

Data Badan Perencanaan Pembangunan Nasional, Badan Pusat Statistik, dan United Nation Population Fund, memprediksi jumlah pelaku usaha mikro, kecil, dan menengah (UMKM) di Indonesia pada 2018 sebanyak 58,97 juta orang. Sedangkan jumlah penduduk Indonesia pada tahun 2018 diprediksi mencapai 265 juta jiwa. Deputi Bidang Pembiayaan Kementerian Koperasi dan UKM (Kemkop UKM) Yuana Sutyowati menyebutkan jumlah usaha mikro ada sebanyak 58,91 juta unit, usaha kecil 59.260 unit dan usaha besar 4.987unit dan jumlah wirausaha wanita mencapai 14,3 juta orang, dalam hal ini jumlah ini meningkat 1,6 juta orang dari jumlah 12,7 juta orang tahun sebelumnya (Indrastiti, 2018; Pramudya, 2020; Siagian \& Indra, 2019).

Para pedagang UKM perlu meningkatkan kemampuan kewirausahaan, organisasi, manajemen, ketrampilan teknis usaha yang digeluti, kemampuan inovasi, manajemen keuangan seperti perencanaan keuangan, maupun kemampuan menyusun proposal kelayakan usaha sangat dibutuhkan guna menjadikan UKM ataupun wirausaha dengan produktivitas dan daya saing tinggi. Pengembangan kewirausahaan ini diharapkan akan meningkatkan daya tahan bangsa, memperluas kesempatan kerja dan menanggulangi masalah kemiskinan, yang terbukti pada saat krisis ekonomi usaha kecil menengah dan koperasi yang mengandalkan bahan baku lokal dan memiliki keunggulan kompetitif mampu bertahan dan bahkan berkembang. Tetapi agar hal diatas dapat bersinergi maka semua sangat tergantung kepada unsur-unsur apa yang diharapkan dari masyarakat. Artinya, Jika ada sebuah usaha yang menjadi unggulan dan masyarakat sendiri diarahkan unsur kewiraswastaannya keberadaan peluang usaha akan bisa memberdayakan masyarakat yang dituju. Sebaliknya, jika ada sebuah usaha unggulan namun masyarakat tidak diarahkan/di-training maka itu sama saja menihilkan arti pemberdayaan itu sendiri. Oleh karena itu unsur perkuatan organisasi antar dan intra masyarakat dalam proyek mendapat perhatian khusus. Ini diwujudkan dalam bentuk pendampingan, counselling dan pelatihan.

Salah satu permasalahan yang dihadapi sektor UKM (Sumardi, 2017) adalah masalah pemasaran produk. Pemasaran merupakan hal yang sederhana dan secara intuisi merupakan filosofi yang menarik. Konsep ini menyatakan bahwa alasan keberadaan sosial ekonomi bagi suatu organisasi adalah memuaskan kebutuhan konsumen dan keinginan tersebut sesuai dengan sasaran perusahaan. Kurangnya networking maupun relasi dapat mengurai kinerja pemasaran sektor UMKM, sehingga perlu sebuah konsep pemasaran bagi UMKM yang memudahkan pelaku usaha sektor UMKM untuk membuka jaringan pemasaran, khususnya dalam usaha menginformasikan dan mempromosikan produknya.

Sedangkan kesuksesan sebagai seorang wirausaha atau pedagang UKM diartikan sebagai kesuksesan dalam memasarkan produk yaitu memasarkan suatu produk harus memiliki cara jual yang unik atau yang biasa disebut dengan unique selling proposition (USP) (lihat contoh pada Gambar 1). Dengan memiliki USP ini setiap produk akan memiliki perbedaan dan keistimewaan tersendiri. Hal tersebut sering kali diabaikan akan tetapi sangat penting untuk menciptakan produk ideal yang dicintai oleh pelanggan. USP yang kuat dan bagus akan mempertahankan produk anda tetap berdiri menjadi pesaing yang aktif untuk menyediakan produk yang ideal di mata pelanggan.

USP ini sendiri terdiri dari tiga unsur utama (Winda, 2014) yaitu: (1) Unique, karakteristik produk yang membuat setiap produk anda menjadi berbeda dan istimewa; (2) Selling, bagaimana menarik atau membujuk masyarakat untuk membeli produk dan jasa yang ditawarkan; (3) Proposition, proposal, saran atau usul untuk diterima. Mengapa setiap bisnis atau produk harus memiliki USP? Sebagaimana yang biasa dialami oleh calon pelanggan bahwa 
mereka sering kali kesulitan dalam memilih produk yang dapat dipercaya. Pemilihan ini menjadi sebuah ketakutan bagi calon pelanggan yang tidak memiliki pengalaman dan tidak mengetahui perbedaan antara produk yang satu dengan yang lainnya.

Hal demikianlah yang mendorong anda sebagai marketer untuk memberikan proposisi penjualan yang unik (USP), sehingga calon pelanggan dapat melihat bahwa produk yang anda tawarkan tersebut benar-benar berbeda, istimewa dan mengesankan.

Berikut beberapa cara membangun USP suatu produk (Anggrianto et al., 2019): Pertama, tempatkan diri anda sebagai pelanggan, dengan hal ini maka produsen akan mengetahui apa yang sebenarnya diinginkan oleh pelanggan. Misalnya jika anda ingin membuka sebuah café, tidak hanya makanan yang pelanggan butuhkan. Anda harus mencari tahu apa yang dapat membuat pelanggan kembali lagi serta mengabaikan pesaing anda. Anda harus menjawab semua kebutuhan pelangggan seperti kualitas, kuantitas, keramahan, kebersihan, kesopanan dan keandalan. Kedua, Harga bukan lah satu-satunya alasan untuk memilih suatu produk. Mungkin saja banyak pesaing yang menjual produk yang sama dengan harga yang lebih menarik disbanding harga yang nda tawarkan. Oleh karena itu anda sebagai pesaing harus mengetahui motivasi lain yang mendorong pelangan untuk memutuskan memilih suatu produk. Anda harus mengetahui beberapa motif pelanggan membeli makanan disebuah café, contohnya, jenis rasa makanan, ras, usia, jenis kelamin, lokasi geografis, tekanan teman sebaya, kenyamanan dan lain-lain. Ketiga, jika anda ingin menjual produk kosmetik, yang paling ditekankan disini adalah memberikan promosi yang berorientasi pada psikologis pelanggan. Mereka akan membeli produk yang dapat memenuhi keinginan bukan semata-mata kebutuhan mereka seperti untuk awet muda, mencerah wajah, glamor dan mewah. Belajar dari pengalaman adalah yang sangat baik, dan meminimalisir resiko untuk gagal.

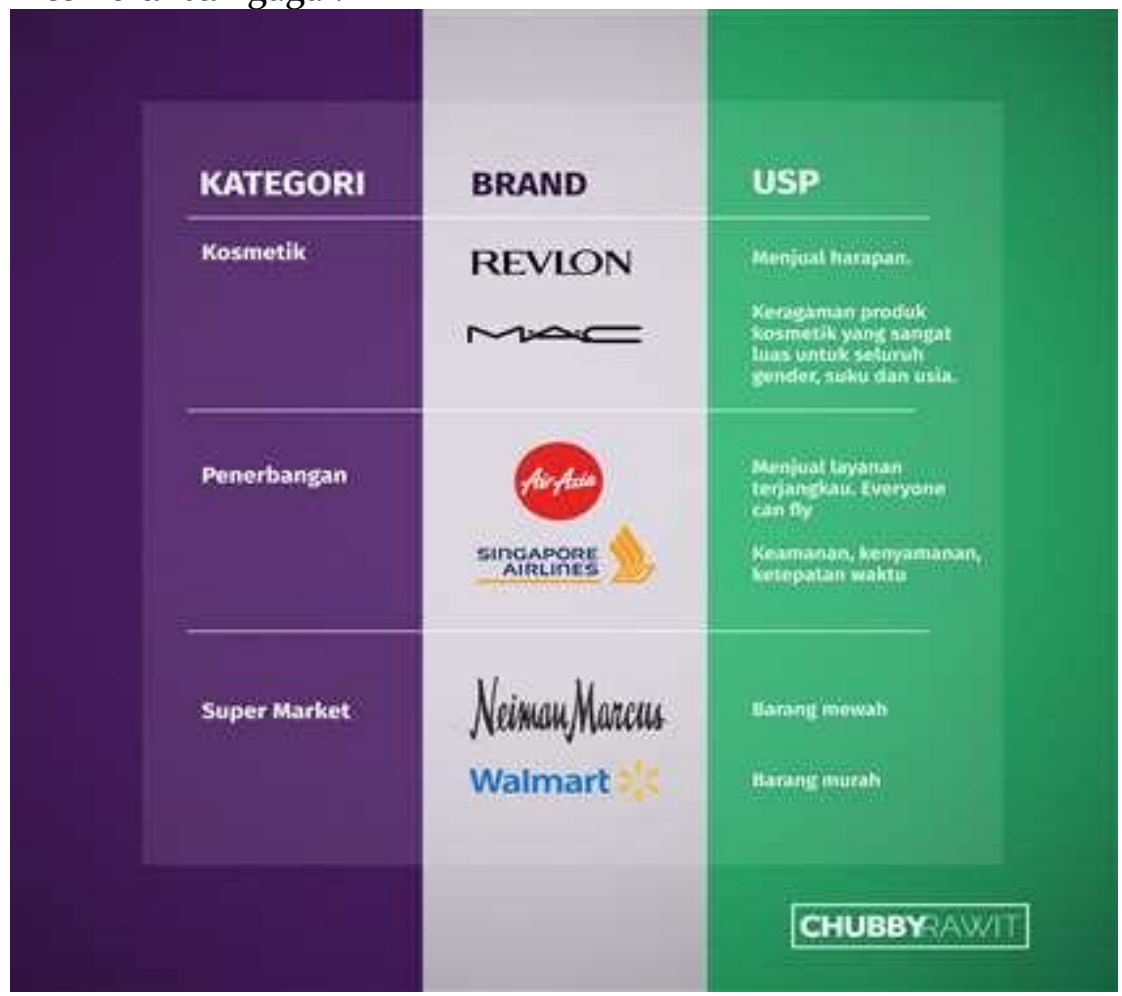

Gambar 1. Contoh Unique Selling Proposition (USP)

Sebagai ilustrasi, misalnya saja usaha minuman jus, dapat ditawarkan beberapa nilai lebih seperti (diakses di ukmindonesia.id): (1) Dari pilihan bahan baku (varian jus yang dimiliki unik dan organik, yaitu pala, jeruk nipis, lemon jahe, dan lain-lain); (2) Metode pengolahan (proses produksinya sudah mendapatkan sertifikasi halal, sehingga sudah terjamin kebersihan dan kehalalannya); (3) Cara penjualan (beli 4 gratis 1, setiap jumat gratis untuk perempuan atau anak-anak, bisa dibeli secara online, ada paket reseller, dan sebagainya); (4) Cara pelayanan 
(bungkus atau kemasannya bagus sehingga konsumen senang dan bisa menjadikan produk jusnya sebagai hadiah; ada layanan antar gratis, dan lain-lain); (5) Cara pembayaran (bisa terima semua berbagai cara pembayaran dari tunai, transfer, dengan kartu debit, kartu kredit, ada skema cicil untuk reseller, dan lain-lain); (6) Layanan pasca penjualan (garansi ganti produk jika kualitas jus ada yang rusak, ada hadiah khusus bagi pelanggan setia, dan lain-lain).

Permasalahan selanjutnya (Mauliyah \& Kirom, 2018) adalah permasalahan yang kerap muncul dalam suatu UKM yaitu mengenai laporan tentang biaya yang dikeluarkan selama proses produksi dalam suatu periode. Dalam memperoleh informasi biaya produksi tersebut dibutuhkan pengolahan data sesuai teori serta prinsip akuntansi, sehingga dapat juga digunakan dalam penentuan harga pokok penjualan yang tepat. Penentuan Harga Pokok penjualan menjadi hal yang sangat penting karena dapat menjadi hal yang menentukan pendapatan para pelaku UKM. Harga Pokok penjualan merupakan acuan bagi para pelaku usaha untuk menentukan harga jual produk, sehingga pelaku usaha dapat memperhitungkan laba yang akan diperoleh agar tidak rugi.

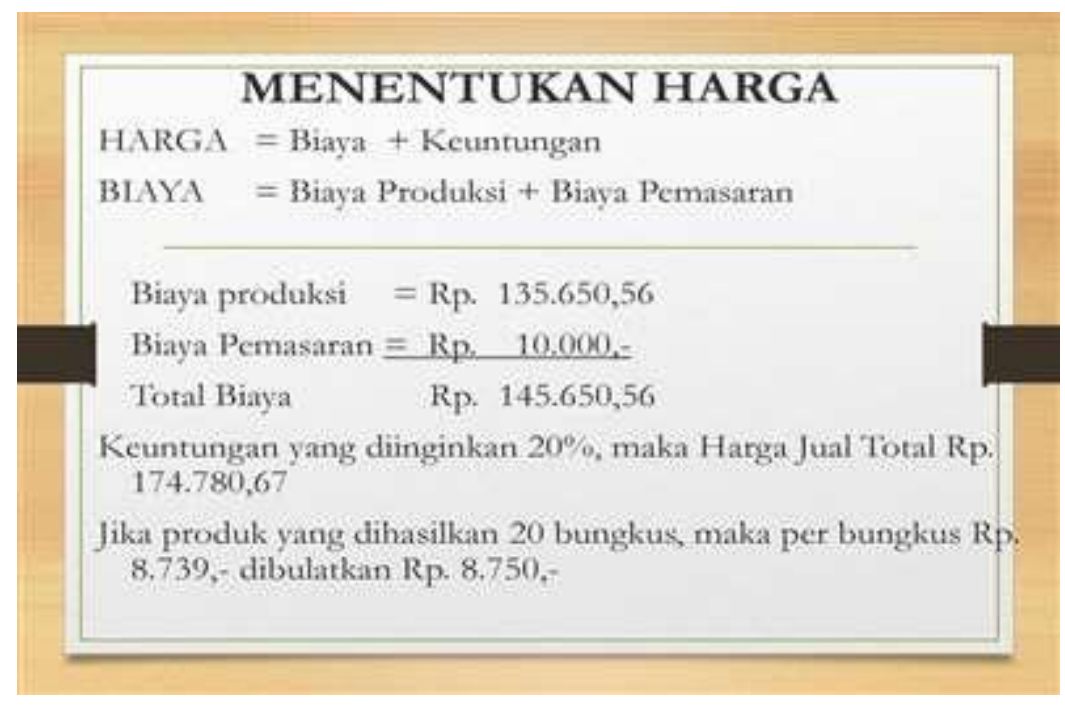

Gambar 2. Perhitungan Sederhana Penentuan Harga Jual

Para pedagang UKM ini berada di lokasi yang bernama Desa Segara Jaya yang dibentuk tahun 1945 merupakan salah satu Desa di Kecamatan Tarumajaya, Bekasi Jawa Barat. Selain Desa Segara Jaya terdapat 7 Desa lain di Kecamatan Tarumajaya. Diantaranya: Desa Pusaka Rakyat, Desa setiasih, Desa Pahlawan Setia, Desa Setia Mulya, Desa Segara Makmur, Desa Pantai Makmur, dan Desa Samudra Jaya. Desa Segara Jaya berbatasan dengan Laut Jawa disebelah utara, hal ini yang menyebabkan pada awalnya sebagian besar masyarakat nya berprofesi sebagai nelayan. Walaupun kemudian dengan semakin berkembangnya waktu di Desa Segara Jaya mulai banyak dibangun pabrik, selain itu terdapat pula Pembangkit Listrik Tenaga Uap (PLTU) Muara Tawar. Dengan jumlah penduduk sebanyak 20.731 jiwa, mayoritas masyarakat Desa Segara Jaya bermata pencaharian sebagai karyawan (50\%), nelayan 30\%, dan sisa nya $20 \%$ berprofesi sebagai petani. Berikut adalah hasil wawancara di Desa Segara jaya terkait produk:

Kadus 1: (1) Banyak Ibu-ibu rumah tangga mempunyai usaha rumahan membuat gorengan dan aneka minuman es, namun terkendala dalam masalah pemasaran dan finansial; (2) Banyak yang berprofesi sebagai Nelayan mengalami kendala dalam pemasaran. Mereka menjual dagangannya kepada tengkulak yang membelinya dengan harga murah namun kemudian menjualnya ke swalayan dengan harga mahal; dan (3) Terdapat kelompok pembuat abon ikan Tuna dengan masa expired satu tahun. Kendalanya adalah permodalan dan terbatasnya pemasaran.

Kadus 2: Terdapat beberapa usaha yang sedang berkembang di kalangan warga seperti pengupasan kerang, batik sarkasi dan tempe. Namun usaha mereka masih kurang berkembang 
JPPM (Jurnal Pendidikan dan Pemberdayaan Masyarakat), 7 (1), 2020 - 69

Yunika Murdayanti, Susi Indriani, Etty Gurendrawati, IGKA Ulupui, Suherman

karena masalah pemasaran dan finansial. Kadus 3: Termasuk dusun yang menerima proyek Desa regulasi.

Kadus 5: Bpk Narsiwan, yaitu (1) Dusun ini pernah mendapatkan program Bimteks dan modal; (2) 50\% penduduk di dusun ini berprofesi sebagai petani; dan (3) Warga ada yang mempunyai usaha di bidang bakery, produksi tempe dan tambak ikan. Namun usaha masih kurang berkembang karena kekurangan modal dan terhambat dalam masalah pemasaran.

Kadus 6: (1) Warga yang banyak berprofesi sebagai nelayan, sedang berusaha mengembangkan usaha kerang hijau; (2) Memohon adanya pembinaan pengelolaan pangan kerang hijau dan bagaimana memperluas pasar

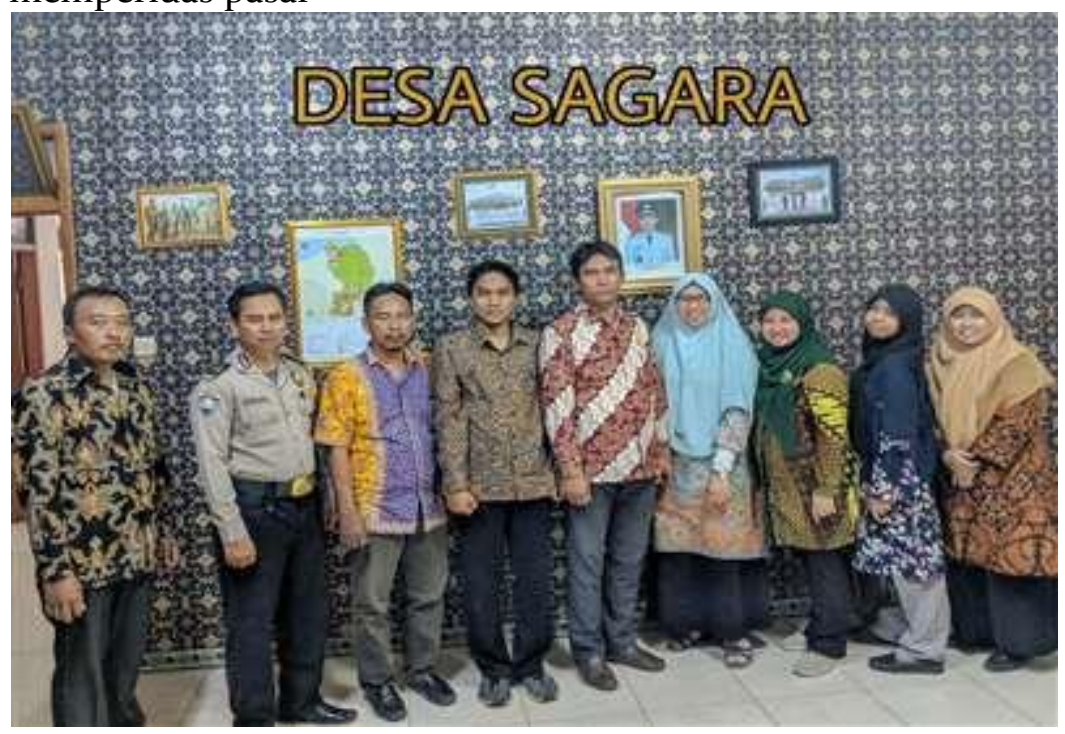

Gambar 3. Pejabat Desa Segara Jaya

Beberapa permasalahan terdapat yang dialami oleh pedagang UKM Desa Segara Jaya ini adalah:

Aspek Pendidikan Kewirausahaan

Pemberdayaan pedagang UKM ini adalah sebuah proses dengan mana orang menjadi cukup kuat untuk berpartisipasi dalam kegiatan dan usaha dalam rangka kompetisi dan survive. Masih ditemukan adanya kelemahan dalam pengetahuan akan kewirausahaan. Minimnya akses pengetahuan dan program pendidikan kewirausahaan bagi para pedagang UKM akan memunculkan kekhawatiran semakin tertinggalkan pemahaman intelektual maupun keterasahan softskill mereka.

Aspek Manajemen Produk (Unique Selling Proposition (USP))

Masalah pemasaran produk merupakan permasalahan utama oleh para pedagang UKM. Pemasaran merupakan hal yang sederhana dan secara intuisi merupakan filosofi yang menarik. Konsep ini menyatakan bahwa alasan keberadaan sosial ekonomi bagi suatu organisasi adalah memuaskan kebutuhan konsumen dan keinginan tersebut sesuai dengan sasaran perusahaan. Berdasarkan hasil wawancara, mayoritas para pedagang di Desa Segara Jaya terjerat oleh para tengkulak karena tidak mengerti bagaimana memasarkan produk sendiri agar bisa masuk ke dalam pasar besar sepert supermarket atau minimarket yang berada di lingkungan sekitar. Hal tersebut juga dikaitkan oleh sulitnya memasarkan suatu produk tetapi harus memiliki cara jual yang unik atau yang biasa disebut dengan unique selling proposition (USP). Dengan memiliki USP ini setiap produk akan memiliki perbedaan dan keistimewaan tersendiri.

Aspek Penentuan Harga Jual

Selain melakukan Strategi Unique Selling Proposition, penentuan Harga Pokok juga penjualan menjadi hal yang sangat penting karena dapat menjadi hal yang menentukan pendapatan 
JPPM (Jurnal Pendidikan dan Pemberdayaan Masyarakat), 7 (1), 2020 - 70

Yunika Murdayanti, Susi Indriani, Etty Gurendrawati, IGKA Ulupui, Suherman

para pelaku UKM. Harga Pokok penjualan merupakan acuan bagi para pelaku usaha untuk menentukan harga jual produk, sehingga pelaku usaha dapat memperhitungkan laba yang akan diperoleh agar tidak rugi. Tujuan ini agar para pedagang UKM tidak kesulitan untuk menambah modal yang bisa diperoleh dari hibah pemerintah ataupun perbankan.

Pengembangan Desa Segara Jaya ini yang rencana akan dijadikan Desa Binaan oleh Fakultas Ekonomi diharapkan memiliki tujuan yang terintegrasi yaitu tujuan yang merupakan sinergi dan kolaborasi berbagai pihak, seperti pemerintah, BUMN, perguruan tinggi, swasta, media dan masyarakat, dalam membangun dan mewujudkan UKM yang maju, mandiri dan modern. Sementara untuk peningkatan kapasitas SDM UKM, dalam hal ini FE UNJ bekerjasama dengan berbagai pihak menfasilitasi pelatihan-pelatihan ke depannya seperti implementasi technopreneur, fasilitasi pemasaran produk KUMKM melalui pengembangan e-commerce dan sebagainya.

\section{Permasalahan Mitra}

Berdasarkan analisis situasi diatas yang berlandaskan hasil wawancara dari penelitan terdahulu, disebutkan dibawah ini hasil permasalahan dari masing-masing mitra: (1) Rendahnya pengetahuan pendidikan kewirausahaan yang mengakibatkan minimnya keterampilan menjadi seorang wirausaha yang Tangguh; (2) Kendala masih banyak para pedagang kesulitan untuk memasarkan produknya; (3) Terjerat oleh Tengkulak; (4) Kesulitan untuk memperoleh akses modal guna memperluas produknya; (5) Minim pengetahuan untuk menentukan harga jual yang sesuai dengan produk yang dihasilkan.

\section{METODE}

\section{Solusi Permasalahan}

Informasi mengenai beberapa permasalahan yang dihadapi oleh Desa Segara Jaya tersebut tentunya harus sesegera mungkin untuk diatasi sebagai salah satu solusi dalam meningkatkan pendidikan kewirausahaan, manajemen produk USP, penentuan biaya dan laporan harga jual. Melalui program usulan kegiatan IPTEKS ini dan berdasarkan analisis kebutuhan yang telah dilaksanakan, tim pengabdi mencoba menawarkan solusi terhadap permasalahan tersebut dengan sentuhan IPTEKS, yaitu melalui kegiatan pokok (1) peningkatan pemahaman dan keterampilan kewirausahan, (2) peningkatan kemampuan manajemen produk atau USP, (3) peningkatan kemampuan menentukan harga jual yang kompetitif dan (4) peningkatan kemampuan manajerial mitra.

Adapun rincian solusi terkait dengan permasalahan mitra adalah, Pertama, Pengelolaan manajerial termasuk manajemen memasarkan produk atau USP dan pengelolaan penentuan harga jual yang baik dan penataan penerimaan dan pengeluaran keuangan dari penjualan produk yang dimiliki serta diperlukannya buku pencatatan mengenai arus kas dari masingmasing produk yang dimiliki. Kedua, Adanya program edukasi kewirausaahaan yang bertujuan untuk membentuk pengembangan kepribadian seorang pedagang UKM atau wirausaha yang tangguh. Ketiga, Menguasi kompetensi dalam melakukan perhitungan harga pokok penjualan dan membuat laporan biaya produksi yang baik dengan tujuan untuk menghindari kesalahan pencatatan dan bisa membuat harga yang kompetitif di pasaran.

Luaran dari solusi tersebut diharapkan: Pertama, pelatihan pengetahuan pendidikan kewirausaahaan, bertujuan: (1) Kemampuan kelompok sasaran meningkat 85\% dalam bidang kewirausahaan; (2) Kelompok sasaran mampu membuat dirinya menjadi seorang entrepreneur dengan keunggulan kompetitif mampu bertahan dan bahkan berkembang. Kedua, Peningkatan kemampuan manajerial pemasaran produk dengan Unique Selling Proposition (USP), dengan tujuan: (1) Peningkatan kemampuan pedagang UKM dalam bidang Unique Selling Proposition (USP) sebesar 80\%; (2) Peningkatan kemampuan pedagang UKM dalam bidang manajemen produk jasa dan layanan sebesar $75 \%$. 


\section{JPPM (Jurnal Pendidikan dan Pemberdayaan Masyarakat), 7 (1), 2020 - 71}

Yunika Murdayanti, Susi Indriani, Etty Gurendrawati, IGKA Ulupui, Suherman

Ketiga, Pelatihan pedagang UKM dalam membuat biaya produksi sehingga bisa menentukan harga jual yang kompetitif, dengan tujuan: (1) Kemampuan kelompok sasaran meningkat dalam bidang akuntansi manajemen melalui proses perhitungan harga jual yang baik sebesar 9o\%; (2) Tersedianya pencatatan biaya produksi sebagai sarana perbaikan keuangan dan persediaan usaha sebesar $95 \%$.

Tahapan Pelaksanaan Kegiatan

Pelaksanaan kegiatan pengabdian ini mengikuti aktivitas pelaksanaan penelitian tindakan yang terdiri dari Perencanaan, Persiapan, Pelaksanaan (tindakan), Observasi dan Evaluasi serta Refleksi.

\section{Perencaaan}

Kegiatan perencanaan sebagai berikut: (1) Melakukan kordinasi dengan LPPM Universitas Negeri Jakarta; (2) Sosialisasi Kegiatan Pengabdian Masyarakat Desa Binaan; (3) Penyusunan program pengabdian berdasarkan hasil analisis situasi, analisis pedagang UKM, jenis pencatatan keuangan, jumlah produk, pemasaran produk dan pengenalan pendidikan kewirausahaan.

\section{Pelaksanaan Tindakan}

Pelaksanaan Tindakan meliputi, (1) Pembentukan dan pendampingan kelompok pedagang UKM yang dapat mengatasi kesulitan dalam dalam penentuan harga jual dan pemasaran produk; (2) Pelatihan tentang kewirausahaan, strategi penentuan harga dan membuat produk unik untuk dapat dipasarkan yang lebih luas; (3) Penguasaan praktek penerimaan dan pengeluaran serta mencatat dengan benar jumlah produk serta mampu menyusun laporan harga pokok penjualan; (4) Menambah pengetahuan pengurus atau pengelola koperasi tentang perkembangan manajemen bisnis.

Observasi dan Evaluasi

Kegiatan observasi dilakukan secara langsung oleh tim pelaksana. Observasi berupa hasil kerja peserta terhadap strategi penentuan harga jual dan pemasaran produk. Proses evaluasi dilaksanakan untuk mengetahui kekurangan dan kendala dalam pelaksanaan kegiatan pengabdian.

Refleksi

Refleksi dilakukan bersama antara tim dan peserta. Hal ini dilakukan untuk mengetahui seluruh proses pelaksanaan kegiatan.

Metode Pendekatan yang Ditawarkan

Transfer IPTEKS yang dilakukan tim pada tiap tahapan yang diterima oleh mitra dilakukan melalui proses, mendengar, mengetahui, mencoba, mengevaluasi, menerima, meyakini dan melaksanakan yaitu: (1) Wawancara dengan pimpinan atau sekretaris desa setempat yang bersedia untuk dibantu pengelolaan para pedagang UKM nya agar dapat bersaing dengan UKM yang sejenis dan laku dipasaran; (2) Ceramah dan tatap muka; (3) Pengenalan konsep kewirausahaan, penentuan harga dan pemasaran produk yang baik secara mendalam kepada para pedagang UKM; (4) Mengadakan diskusi untuk dapat menghasilkan timbal balik mengenai pelaksanaan pemberian materi dan kendalanya dalam mengelola produk.

Partisipasi Mitra dalam Pelaksanaan Program

Desa Segara Jaya yang menjadi mitra dalam kegiatan IPTEKS ini berpartisipasi aktif dalam setiap kegiatan yang diselenggarakan. Sedangkan dalam kegiatan pelatihan, disamping berpartisipasi sebagai peserta, mitra berperan dalam menyediakan tempat pelatihan, ikut mensosialisasikan program pelatihan yang akan dilaksanakan kepada pedagang UKM lain dan ikut bekerja 


\section{JPPM (Jurnal Pendidikan dan Pemberdayaan Masyarakat), 7 (1), 2020 - 72}

Yunika Murdayanti, Susi Indriani, Etty Gurendrawati, IGKA Ulupui, Suherman

sama dengan tim dalam mengadakan konsumsi pelatihan. Sehingga partisipasi mitra sangat mendukung terhadap pelaksanaan program kegiatan IPTEKS ini secara keseluruhan.

\section{Rancangan Evaluasi Pelaksanaan Program dan Keberlanjutan Program}

Rancangan evaluasi dalam kegiatan ini ditetapkan untuk mengevaluasi terhadap penguasaan materi pelatihan oleh para pedagang UKM, pelaksanaan kegiatan dan dampak kegiatan. Secara rinci rancangan evaluasi terhadap kegiatan ini disajikan berikut ini: (1) Peningkatkan pengetahuan dalam menentukan harga jual sendiri sehingga dapat menghasilkan suatu laporan biaya yang baik; (2) Peningkatan kemampuan keterampilan manajerial baik dari manajemen pemasaran dan menghasilkan suatu produk yang unik; (3) Pengelolaan sumber daya yang baik; (4) Peningkatan keuletan dan ketelitian dalam melakukan menghitung jumlah produk dengan adanya pencatatan yang baik; (5) Peningkatan kreatifitas.

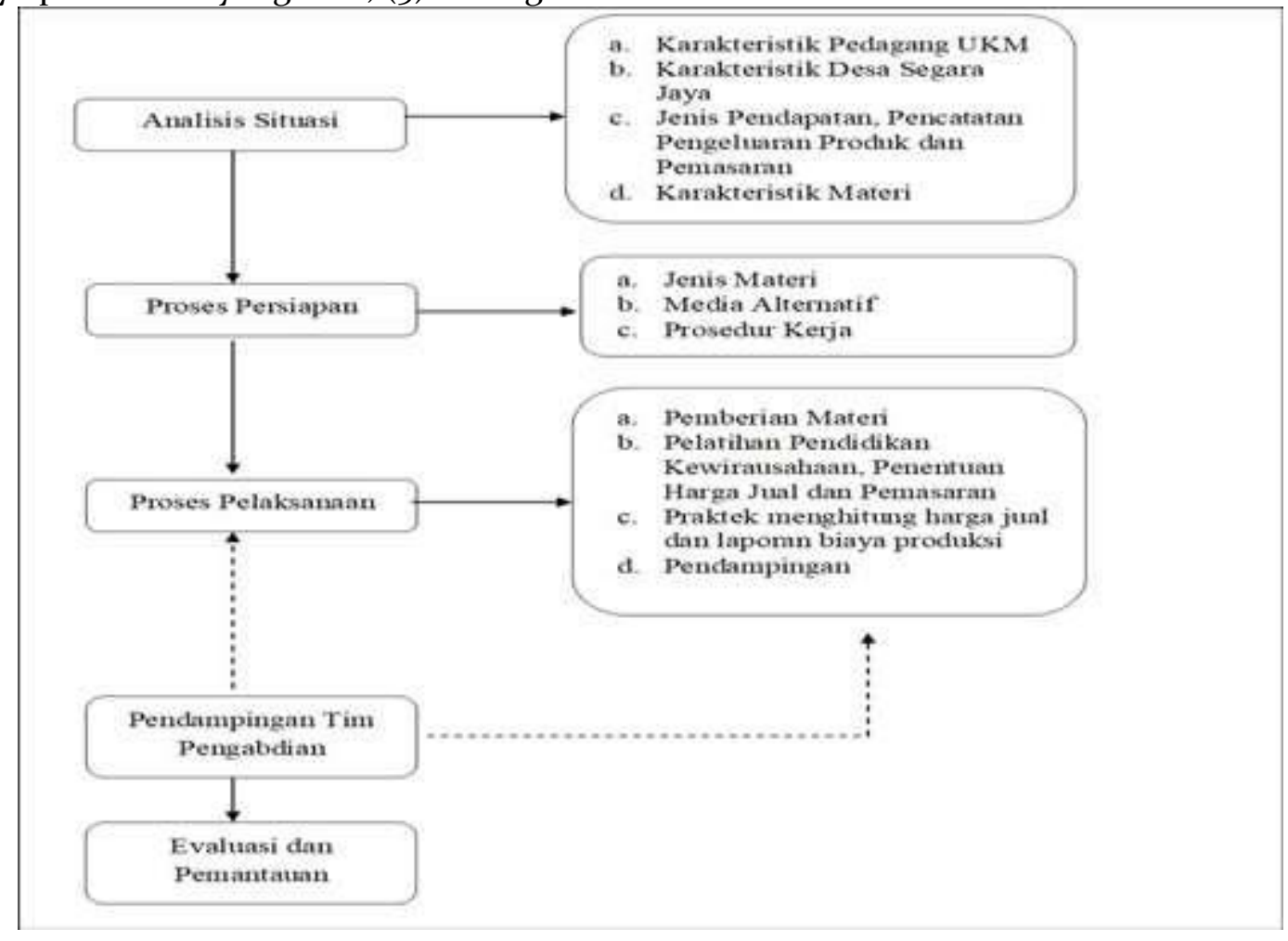

Gambar 4. Skema Kegiatan PKM

\section{HASIL DAN PEMBAHASAN}

\section{Hasil Kegiatan}

Kegiatan PKM Pedagang UKM di Desa Segara Jaya dalam Mengoptimalkan Nilai Tambah Pendapatan melalui Implementasi Unique Selling Proposition dan Strategi Penentuan Harga Jual yang ditujukan bagi pedagang UKM desa Segara Jaya, Kecamatan Tarumanegara, Bekasi dilaksanakan di Gedung Aula Serbaguna Desa Segara Jaya, Bekasi pada Hari Rabu tanggal 4 September 2019. Pelatihan ini diisi oleh 3 orang narasumber dan dibantu oleh tim panitia.

Pelatihan ini diikuti 54 orang peserta yang merupakan pelaku UKM di Desa Segara Jaya. Desa Segara Jaya merupakan salah satu desa yang akan menjadi desa binaan Fakultas Ekonomi UNJ. Pelaksanaan pelatihan ini pun berjalan dengan lancar berkat kerjasama dan partisipasi dari pihak sekolah maupun dari tim panitia UNJ yang bertujuan untuk menambah pengetahuan dan kemampuan dalam hal kewirausahaan, manajemen produk USP, penentuan biaya dan laporan harga jual.

Pelatihan berlangsung selama 1 hari, yaitu pada tanggal 4 September 2019 dari jam o8.oo sampai dengan jam 15.0o WIB. Penekanan pelatihan ini terletak pada sejauh mana bertambah- 


\section{JPPM (Jurnal Pendidikan dan Pemberdayaan Masyarakat), 7 (1), 2020 - 73}

Yunika Murdayanti, Susi Indriani, Etty Gurendrawati, IGKA Ulupui, Suherman

nya pemahaman dan kemampuan peserta dalam hal kewirausahaan, manajemen produk USP, penentuan biaya dan laporan harga jual. Yaitu bagaimana peserta menjadi mengetahui pengertian dan karakteristik kewirausahaan, manajemen produk USP, penentuan biaya dan laporan harga jual, praktek para peserta untuk melakukan sistem penjualan yang unik dan menentukan harga jual yang kompetitif.

Pelatihan mengenai Unique Selling Proposition dan Strategi Penentuan Harga Jual disampaikan pada sesi ke enam, setelah ishoma. Adapun materi yang disampaikan adalah:

\section{Pengenalan USP (Unique Selling Proposition)}

Pemasaran adalah mengidentifikasi dan memenuhi kebutuhan manusia dan sosial dengan cara yang menguntungkan (Kotler, 2018). Dalam melakukan pemasaran dibutuhkan kerja dan keterampilan. Kesuksesan sebagai seorang wirausaha atau pedagang UKM diartikan sebagai kesuksesan dalam memasarkan produk yaitu memasarkan suatu produk harus memiliki cara jual yang unik atau yang biasa disebut dengan unique selling proposition (USP). Dengan memiliki USP ini setiap produk akan memiliki perbedaan dan keistimewaan tersendiri. Hal tersebut sering kali diabaikan akan tetapi sangat penting untuk menciptakan produk ideal yang dicintai oleh pelanggan. USP yang kuat dan bagus akan mempertahankan produk anda tetap berdiri menjadi pesaing yang aktif untuk menyediakan produk yang ideal di mata pelanggan. USP ini sendiri terdiri dari tiga unsur utama yaitu: (1) Unique, karakteristik produk yang membuat setiap produk anda menjadi berbeda dan istimewa; (2) Selling, bagaimana menarik atau membujuk masyarakat untuk membeli produk dan jasa yang ditawarkan; dan (3) Proposition, proposal, saran atau usul untuk diterima.

Beberapa cara membangun USP suatu produk: (1) Menempatkan diri sebagai pelanggan, dengan hal ini maka produsen akan mengetahui apa yang sebenarnya diinginkan oleh pelanggan; (2) Harga bukanlah satu-satunya alasan untuk memilih suatu produk. Mungkin saja banyak pesaing yang menjual produk yang sama dengan harga yang lebih menarik dibanding harga yang ditawarkan; (3) Memberikan promosi yang berorientasi pada psikologis pelanggan.

Pada sesi materi USP ini membantu menjawab permasalahan mitra yaitu penjelasan mengenai penentuan harga jual yang baik dan penataan penerimaan dan pengeluaran keuangan dari penjualan produk yang dimiliki serta diperlukannya buku pencatatan mengenai arus kas dari masing-masing produk yang dimiliki serta edukasi kewirausaahaan yang bertujuan untuk membentuk pengembangan kepribadian seorang pelaku UKM atau wirausaha yang tangguh. Materi dimulai dengan penyampaian mengenai apa yang dimaksud dengan jiwa kewirausaahaan, dilanjutkan mengenai metode-metode atau cara pemasaran produk dengan Unique Selling Proposition (USP) dan cara membuat biaya produksi sehingga peserta mampu meningkatkan pelayanan dalam memasarkan produknya produknya dan menentukan harga jual yang kompetitif. Dalam hal ini, peserta diajarkan untuk bisa menjadi kreatif dalam memanajemen produk yang dihasilkan, mulai dari pemilihan bahan baku, proses produksi, pemasaran, hingga layanan pasca jual.

Peserta juga diberikan materi mengenai penentuan harga jual yang kompetitif. Submateri ini diarahkan dengan pembuatan harga pokok penjualan sederhana yang bisa dilakukan perhitungan di buku catatan manual mulai dari menentukan biaya-biaya yang dikeluarkan lalu menentukan keuntungan yang diinginkan dan menghitung harga jual, sebagai contoh:

\section{HARGA = BIAYA + KEUNTUNGAN \\ BIAYA = BIAYA PRODUKSI + BIAYA PEMASARAN}

Biaya Produksi $=$ Rp135.650,56,-

Biaya Pemasaran $=\underline{\text { Rpio.ooo, }-}+$

Total Biaya Rp145.650,56,-

Keuntungan yang diinginkan 20\%, maka Harga Jual Total Rp174.78o,67,-

Jika produk yang dihasilkan 20 bungkus, maka per bungkus Rp8.739,-- dibulatkan Rp8.750,- 
Pengenalan Harga Pokok Penjualan

Dalam menetapkan harga, pelaku usaha sebaiknya memastikan pemulihan dalam jangka panjang atas semua biaya dan laba bahkan dalam kondisi yang sulit sekalipun. Penentuan Harga Pokok penjualan menjadi hal yang sangat penting karena dapat menjadi hal yang menentukan pendapatan para pelaku UKM. Harga Pokok penjualan merupakan acuan bagi para pelaku usaha untuk menentukan harga jual produk, sehingga pelaku usaha dapat memperhitungkan laba yang akan diperoleh agar tidak rugi.

Komponen Harga Pokok Penjualan:

1. Persediaan Awal Barang Dagangan

2. Persediaan Akhir Barang Dagangan

3. Pembelian bersih

Faktor-Faktor Yang Mempengaruhi Harga Jual:

1. Customers atau pelanggan

2. Competitors atau pesaing

3. Costs atau biaya

Tujuan Penetapan Harga Jual:

1. Memaksimalkan Laba atau Keuntungan,

2. Memaksimalkan Pendapatan,

3. Memaksimalkan Pangsa Pasar dan

4. Kepemimpinan mutu.

Penetapan Harga Jual:

1. Penetapan harga jual oleh pasar (Market Pricing)

2. Penetapan harga jual oleh pemerintah (Government Controlled Pricing)

3. Penetapan harga jual yang dapat dikontrol oleh perusahaan

Metode Penentuan Harga Jual:

1. Maksimalisasi laba

2. Tingkat pengembalian atas modal yang digunakan

3. Biaya konversi

4. Marjin kontribusi

5. Biaya standar

\section{Pembahasan}

Pelatihan ini mendapat dukungan yang baik dari masyarakat desa Segara Jaya sehingga pelatihan dapat dilaksanakan dengan lancar. Pemberian materi disampaikan dengan metode presentasi yang kemudian dilanjutkan dengan sesi tanya jawab. Peserta mendapatkan materi mengenai bagaimana menjadi wirausahawan yang tangguh, melakukan pemasaran produk dengan Unique Selling Proposition (USP), dan menentukan harga jual produk.

Peserta yang memiliki latar belakang pelaku UKM di berbagai bidang tentunya memiliki tantangan tersendiri bagi narasumber untuk dapat menyampaikan materi secara menarik. Dari mulai penyajian materi hingga sesi tanya jawab berlangsung dengan cukup antusias. Narasumber berusaha untuk melakukan enggagement dengan peserta sehingga peserta dapat dengan aktif berpartisipasi dan tertarik dengan pelatihan yang diberikan.

\section{Evaluasi Kegiatan}

Kegiatan ini merupakan kegiatan pengabdian masyarakat yang rutin dilakukan di lingkungan Universitas Negeri Jakarta sebagai salah satu dari pelaksanaan Tri Dharma Perguruan Tinggi. Pihak-pihak yang terkait dalam hal ini adalah Universitas Negeri Jakarta selaku pemberi pelatihan, dan masyarkat desa Segara Jaya sebagai peserta pelatihan. Dari lembar evaluasi (Tabel 2) yang diterima oleh panitia diperoleh umpan balik dari para peserta.

Berdasarkan lembar eveluasi (Tabel 1) yang merupakan jawaban responden yang mengumpulkan kuesioner menyampaikan apresiasi bahwa para peserta merasakan manfaat yang 
JPPM (Jurnal Pendidikan dan Pemberdayaan Masyarakat), 7 (1), 2020 - 75

Yunika Murdayanti, Susi Indriani, Etty Gurendrawati, IGKA Ulupui, Suherman

cukup besar setelah mengikuti pelatihan. Sebelum adanya pelatihan mayoritas peserta masih belum membuat laporan keuangan untuk usaha mereka sehingga peserta mengabaikan pengelolaan keuangan yang lain, seperti membuat penganggaran usaha, membuat pencatatan setiap transakasi, dan penentuan harga pokok produksi. Hal ini ditunjukan pertanyaan 1 sampai 10. Setelah adanya pelatihan peseerta diharapkan lebih memiliki kepedulian akan pengelolaan yang baik sehingga bisa menerapkan strategi yang tepat untuk pemasaran produk serta penentuan harga jual yang kompetitif.

Tabel 1. Data Deskriptif Responden

\begin{tabular}{|c|c|c|c|}
\hline \multirow{4}{*}{\multicolumn{2}{|c|}{ 1. Usia }} & $<20$ Tahun & 1 \\
\hline & & 20 - 50 Tahun & 24 \\
\hline & & > 50 Tahun & 5 \\
\hline & & Total & 30 \\
\hline \multirow[t]{2}{*}{2.} & Jenis Kelamin & Wanita & 30 \\
\hline & & Pria & o \\
\hline \multirow[t]{5}{*}{3.} & Bidang Usaha & Berjualan Ikan & 15 \\
\hline & & Berjualan Bakwan Udang & 10 \\
\hline & & Berjualan Bahan Pokok & 4 \\
\hline & & Tukang Urut & 1 \\
\hline & & Total & 30 \\
\hline & Pendidikan Terakhir & SD & 13 \\
\hline & & SMP & 5 \\
\hline & & SMA & 4 \\
\hline & & Perkuliahan & 1 \\
\hline & & Tidak Bersekolah & 7 \\
\hline & & Total & 30 \\
\hline
\end{tabular}

Tabel 2. Evaluasi Pelatihan Berdasarkan Persepsi Responden

\begin{tabular}{|c|c|c|c|c|}
\hline No. & Pernyataan & Ya & Tidak & Total Responden \\
\hline 1. & $\begin{array}{l}\text { Pernahkah Anda membuat laporan keuangan untuk kegiatan } \\
\text { usaha Anda }\end{array}$ & 6 & 24 & 30 \\
\hline 2. & $\begin{array}{l}\text { Apakah sebelumnya Anda pernah mengikuti pelatihan terkait } \\
\text { akuntansi atau laporan keuangan }\end{array}$ & 3 & 27 & 30 \\
\hline 3. & $\begin{array}{l}\text { Apakah Anda mengetahui mengenai jenis-jenis laporan } \\
\text { keuangan yang dapat dibuat oleh UMKM }\end{array}$ & 3 & 27 & 30 \\
\hline 4. & $\begin{array}{l}\text { Apakah dengan menyusun laporan keuangan Anda dapat } \\
\text { mengetahui posisi modal usaha Anda }\end{array}$ & 15 & 15 & 30 \\
\hline 5 . & $\begin{array}{l}\text { Apakah dengan menyusun laporan keuangan Anda dapat } \\
\text { mengetahui posisi laba atau rugi usaha Anda }\end{array}$ & 15 & 15 & 30 \\
\hline 6. & $\begin{array}{l}\text { Apakah Anda mencatat transaksi terkait kegiatan usaha Anda } \\
\text { secara rutin }\end{array}$ & 5 & 25 & 30 \\
\hline 7 . & Apakah Anda menghitung harga jual dengan tepat dan benar & 21 & 9 & 30 \\
\hline 8. & $\begin{array}{l}\text { Apakah Anda membuat perencanaan anggaran kegiatan usaha } \\
\text { Anda }\end{array}$ & 7 & 23 & 30 \\
\hline 9. & $\begin{array}{l}\text { Apakah Anda merasa puas dengan harga jual produk yang } \\
\text { Anda tetapkan }\end{array}$ & 26 & 4 & 30 \\
\hline 10. & $\begin{array}{l}\text { Apakah menurut Anda anggaran dalam kegiatan usaha adalah } \\
\text { penting }\end{array}$ & 27 & 3 & 30 \\
\hline 11. & Apakah materi materi yang disajikan tim pengabdian penting & 25 & 5 & 30 \\
\hline 12. & $\begin{array}{l}\text { Apakah materi materi yang disajikan tim pengabdian } \\
\text { bermanfaat }\end{array}$ & 23 & 7 & 30 \\
\hline 13. & $\begin{array}{l}\text { Apakah materi yang disajikan tim pengabdian dijelaskan secara } \\
\text { jelas }\end{array}$ & 22 & 8 & 30 \\
\hline 14. & $\begin{array}{l}\text { Apakah Anda puas dengan kegiatan pengabdian yang } \\
\text { terlaksana }\end{array}$ & 26 & 4 & 30 \\
\hline
\end{tabular}


JPPM (Jurnal Pendidikan dan Pemberdayaan Masyarakat), 7 (1), 2020 - 76

Yunika Murdayanti, Susi Indriani, Etty Gurendrawati, IGKA Ulupui, Suherman

\section{SIMPULAN}

Sikap kewirausahaan sangat penting diterapkan oleh pelaku usaha, baik usaha besar maupun UKM. Adanya sikap kewirausahaan akan melahirkan kreatifitas pelaku usaha dan kreatifitas ini akan menghasilkan inovasi-inovasi yang dapat meningkatkan nilai perusahaan. Inovasi dalam hal ini bukan hanya mengenai inovasi produk tetapi juga inovasi teknologi, inovasi manajerial, dan inovasi pemasaran.

Salah satu inovasi pemasaran dalam pelatihan ini yaitu dengan menerapkan USP (Unique Selling Proposition). Selain itu materi mengenai penetapan harga jual juga disajikan dalam pelatihan ini.

Kegiatan pelatihan terbukti dapat menambah pengetahuan tentang kewirausahaan, pemasaran yang unik, dan penentuan harga jual. Hasil dari pelatihan ini adalah adanya umpan balik yang disampaikan peserta terhadap ketertarikan pada narasumber yang positif, serta peserta berpendapat bahwa narasumber menguasai materi dan dapat menyampaikan materi dengan jelas dan menarik. Selama proses pelatihan berlangsung para peserta menunjukan antusisme yang sangat baik, yang ditunjukan dengan banyak peserta pelatihan yang berpartisipasi di sesi tanya jawab, dan aktifnya diskusi yang berlangsung selama tanya jawab tersebut. Peserta menyampaikan agar pelatihan serupa dapat dilaksanakan kembali.

Saran dari pelatihan ini adalah kegiatan yang telah dilakukan adalah: (1) Pelatihan ini dapat berkesinambungan dengan periode yang lebih panjang dan materi yang lebih komprehensif; (2) Pelatihan ini melibatkan mahasiswa, yakni dengan menjadikan program desa binaan sebagai tempat KKN agar mahasiswa dapat menerapkan ilmu yang dipelajari; (3) Dapat mentransfer pengetahuan kepada para UKM yang lain terutama yang belum mendapat pelatihan ini.

\section{DAFTAR PUSTAKA}

Anggrianto, S. C., Shaari, N., \& Hamid, N. binti A. (2019). Faktor terpenting dalam membangun unique selling preposition untuk menjangkau konsumen kelas menengah Indonesia.

Universitas Ciputra. http://dspace.uc.ac.id/handle/123456789/3003

Indrastiti, N. (2018). Jumlah pelaku UMKM di 2018 diprediksi mencapai 58,97 juta orang. Kontan.Co.Id. https://keuangan.kontan.co.id/news/jumlah-pelaku-umkm-di-2o18diprediksi-mencapai-5897-juta-orang

Kotler, P. (2018). Manajemen pemasaran (13th ed.). Erlangga.

Mauliyah, N. I., \& Kirom, E. A. (2018). Strategi penentuan harga jual sayuran pada pedagang pasar tradisional (Studi fenomenologi pedagang sayur di Blitar). Jurnal Ecoment Global, 3(1), 77. https://doi.org/10.35908/jeg.v3i1.359

Pramudya, Y. (2020). Membangun dan mengkomunikasikan brand oleh UMKM. Journal of Digital Business and Entrepreneurship, 1(02), 70-80.

Putri, A. S., \& Nailufar, N. N. (2019). Peran UMKM dalam perekonomian Indonesia. Kompas.Com. https://www.kompas.com/skola/read/2019/12/20/120000469/peranumkm-dalam-perekonomian-indonesia?page=all

Siagian, A. O., \& Indra, N. (2019). Pengetahuan akuntansi pelaku usaha mikro kecil dan menengah (UMKM) terhadap laporan keuangan. Syntax Literate; Jurnal Ilmiah Indonesia, 4(12), 17-35. https://doi.org/10.36418/syntax-literate.v4i12.825

Sumardi, S. (2017). e-Marketing: Alternatif dalam pengembangan UMKM di Indonesia. JABE (Journal of Applied Business and Economic), 1(1), 1-6. https://doi.org/10.30998/jabe.vii1.1358

Winda, D. (2014). Pentingnya keunikan proposisi penjualan (unique selling proposition). Kompasiana. https://www.kompasiana.com/gadih/54f5feb4a33311foo18b47cc/pentingnya-keunikan- 
JPPM (Jurnal Pendidikan dan Pemberdayaan Masyarakat), 7 (1), 2020 - 77

Yunika Murdayanti, Susi Indriani, Etty Gurendrawati, IGKA Ulupui, Suherman

proposisi-penjualan-unique-selling-proposition\#

Wuryandani, D., \& Meilani, H. (2013). Peranan kebijakan pemerintah daerah dalam pengembangan usaha mikro, kecil, dan menengah di Provinsi Daerah Istimewa Yogyakarta. Jurnal Ekonomi E Kebijakan Publik, 4(1), 103-115. https://doi.org/10.22212/jekp.v4i1.71 